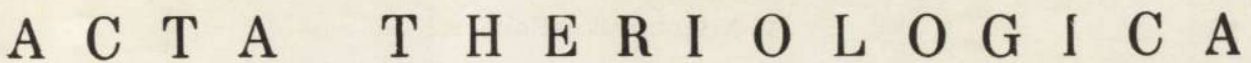 \\ VOL. XVI, 24: $387-400$. \\ BIAEOWIEŻA \\ November, 1971
}

Anna A R Ł A M O W SK A - P A L I D E R

\section{Morphology and Topography \\ of the Caudal Cutaneous Femoral Nerve}

[With 6 Figs.]

\begin{abstract}
Observations were made on 189 animals belonging to the following orders: Primates, Carnivora, Perissodactyla and Artiodactyla. These studies justify the opinion that not all the species of animals examined have a typical caudal cutaneous femoral nerve completely corresponding to the inferior cutaneous femoral nerve in man. The presence of this nerve is characteristic of representatives of the Primates, Perissodactyla, Camelidae and Hippopotamidae. In Carnivora, Suidae and Ruminantia the typical caudal cutaneous femoral nerve has been replaced by another nerve, as shown by its different topography and the way in which it is formed.
\end{abstract}

\section{INTRODUCTION}

The problem of the occurrence and behaviour of the caudal cutaneous femoral nerve in different species of mammals is often a debatable question and one which is variously interpreted by different authors, who are guided by different criteria in defining this nerve. Some of them take into consideration the area it innervates, others the place from which it runs or its origin from the same neuromeres. In consequence we have a situation in which some authors consider that the caudal cutaneous femoral nerve occurs in a given species, while others hold that it does not.

The nerve given this name differs both in man and the Primates and in representatives of other orders. Its topography, however, differs so markedly in different species that there are grounds for doubting whether it is in fact the same nerve which is being referred to.

In man, according to $\mathrm{M}$ a r ciniak (1964), this nerve leaves the pelvic cavity through the almost piriform part of the greater sciatic foramen and runs along the lateral side of the broad ligament of the pelvis. It is covered by the great gluteal muscle and, after passing from under the latter, runs between tuber ischii and the greater femoral trochanter. It then enters the sulcus contained between 
$m$. biceps femoris and $m$. semitendinosus, where it sends out inferior clunial nerves and the perineal branches. This nerve behaves similarly in the gorilla (Pre u$\mathrm{sch}$ oft, 1964). Information given on this nerve in other species of mammals is neither comprehensive nor exhaustive, in fact it is very diverse and even controversial.

The caudal cutaneous femoral nerve has been distinguished and described in representatives of Carnivora. According to Miller (1964) this nerve leaves the pelvic cavity dorsad to the tuber ischii and divides into the perineal branches and caudal clunial nerves. The latter are located in the anosciatic pit and send out branches reaching to the genital organs and to the skin in the region of $\mathrm{mm}$. semimembranosus and semitendinosus. Popesko (1969) also treats the terminal branchings of this nerve as caudal clunial nerves. Humel (1965) and Hen $\mathrm{ning}$ (1965) hold different opinions. The first of these authors states that only those branchings of the caudal cutaneous nerve which innervate the region of skin situated dorsad to tuber ischii can be considered as belonging to the caudal clunial nerves. Henning also (l.c.) considers that only a certain part of this nerve forms the caudal clunial nerves: in the dog the latter arise from special branches of the sacral plexus. This, in the author's opinion, constitutes the difference in the innervation of the posterior part of the glutei in man and dog.

The description of the caudal cutaneous femoral nerve is different in representatives of Perissodactyla. In the horse, after M a r in (1938) and Reimer s (1913), the initial part of this nerve is connected with the sciatic nerve and lies laterally from the sacrosciatic ligament. The trunk of this nerve next divides into the dorsal branch innervating $m$. semitendinosus, and the ventral branch which passes between this muscle and $m$. biceps femoris, ending as the caudal clunial nerves. S is s on (1960) holds a different opinion, since he considers that the caudal cutaneous femoral nerve sonstitutes the ventral branch of the caudal gluteal nerve. The opinions given by Ryži h (1962a) and $\mathrm{Koch}$ (1965) are similar to the foregoing, since they define this nerve as the cutaneous branch of the above nerve. The studies made by $\mathrm{Z}$ ob und ž i ja (1967) show that in $55 \%$ of cases the caudal cutaneous femoral nerve in the horse forms a branch of caudal gluteal nerve; in the remaining number of cases it separates independently from the sacral plexus.

The caudal cutaneous femoral nerve in the tapir (A r łamowska-Palider, 1969) starts from the sacral plexus and runs laterally from the sacrosciatic ligament. Subcutaneously it emerges, as it does in the horse, below tuber ischii and innervates the skin in the region of $m$. biceps femoris and $m$. semitendinosus and also the vertebral head of the latter.

The caudal cutaneous femoral nerve is also distinguished in Artiodactyla. According to Reimers (1913) in the pig this nerve, although running from the sacral plexus, is located along the pericentral side of the sacrosciatic ligament and runs in the direction of tuber ischii, innervating the skin of the upper posterior surface of the thigh. In K a la šnik's (1952) opinion also this nerve in the pig starts from the sacral plexus, but lies along the lateral side of the above ligament on the sciatic nerve. The nerve in question next enters the pelvic cavity and joints the pudendal nerve. After interchanging fibres with this latter nerve, the caudal cutaneous femoral nerve enters the anosciatic pit and innervates the lateral posterior part of the thigh. Ry žih (1964) expresses a completely opposite view, since he states that this nerve in pigs is formed of two cutaneous branches emerging from the pudendal plexus. 
Data on this problem in ruminants are no less contradictory. In the red deer, roe-deer and giraffe the caudal cutaneous femoral nerve separates from the sciatic nerve, runs in the direction of tuber ischii and innervaters only $m$. gluteobiceps and $m$. semitendinosus ( $\mathrm{Franzke}, 1961 ; \mathrm{Heinze}, 1964$ ) or only the proximal part of $m$. biceps femoris (H e in z e, 1962).

Unlike a very large number of authors describing the caudal cutaneous femoral nerve in the cow Ryžih (1962) alone states that this nerve is absent in this species. M a r tin (1938), Goller (1963) and Reimers (1913) on the other hand distinguish this nerve as one of the branches of the sciatic plexus or nerve. According to the above authors the caudal cutaneous femoral nerve in the cow extends to $m$. biceps femoris and $m$. semitendinosus. S chreiber (1956) and $\mathrm{Habel}$ (1966) consider that this nerve consists of two branches - medial and lateral. The first of them, that is, the pelvis branch, enters the pelvic cavity through the lesser sciatic foramen and joins the pudendal nerve. The second, that is, the cutaneous branch (which may be absent) runs either independently, or joins the proximal cutaneous branch of the pudendal nerve. In Popesko's opinion (1969), on the other hand, this nerve runs along the pericentral side of the sacrosciatic ligament and constitutes a branch of the pudendal nerve. The studies made by $\mathrm{Z}$ ieg ler (1931) and Serwatka (1966) show that the caudal cutaneous femoral-nerve in ruminants is, despite its name, a motor nerve serving $\mathrm{m}$. biceps femoris.

In the sheep also, according to Popesk o (1969) - the caudal cutaneous femoral nerve is situated similarly to that in the cow. It leaves the pelvic cavity at the kack of the lateral coccygeal muscle and appears in the anosciatic pit. M a y (1964) holds a totally different opinion and considers a branch of the tibial nerve as the caudal cutaneous femoral nerve, while Ar ła mowska-Palider (1969) considers that this nerve is absent in this animal.

The review given above shows clearly that there is great diversity of opinions and views among the authors referred to. This was inter alia an inducement to study the problem of the caudal cutaneous femoral nerve in some species of mammals. It would seem that elaboration of the morphology and topography of this nerve might, in addition to purely informative value, be of importance when carrying out studies on experimental animals (cat, dog, sheep).

\section{MATERIAI}

Observations were made of the following: 6 individuals of Macaca mulata, 4 of Papio cynocephalus, 30 of Canis familiaris, 30 of Felis catus, 8 of Equus caballus, 2. of Tapirus indicus, 6 of Lama glama, 1 of Camelus bactricinus, 5 of Hippopotamus amphibius, 10 of Sus domestica, 3 of Capreolus capreolus, 2 of Cervus elaphus, 1 of Muntiacus muntiak, 1 of Moschus moschiferus, 2 of Rcngifer tarandus, 30 of Bos taurus, 35 of Ovis aries, 9 of Capra hircus, 1 of Taurotragus oryx, 1 of Boselaphus tragocamelus, 1 of Oryx gazella, 1 of Antilope cervicapra. The material was obtained from collections of the Zoological Museum of Wrocław University, the Wrocław Zoological Garden and breeding farms. 


\section{RESULTS}

In the monkeys examined the inferior cutaneous femoral nerve ${ }^{1}$ ) constitutes one of the independent nerves of the sacral plexus. It begins in the sciatic plexus within the pelvic cavity. As there is no sacrosciatic ligament there is no greater sciatic foramen in these monkeys. Consequently this nerve leaves the pelvic cavity near the greater sciatic incisura of the wing of os ilium and runs parallel to and above the sciatic nerve. It is next located in the immediate vicinity of the perineal nerve and in some cases is even connected with the latter by a common sheath of connective tissue. In its continuation the inferior cutaneous femoral nerve extends to the rear in the direction of tuber ischii and passing between the latter and the greater femoral trochanter reaches the thigh. From the exterior it is covered by $\mathrm{mm}$. gluteus medius and maximus. After reaching the posterior margin of this muscle it emerges from under it on to the surface and lies a broad fascia. It is from here also that it sends out small branches, some of which extend to the skin of the gluteal regions as the inferior (cutaneous) gluteal nerves, and others - the perineal branches - connecting with the superficial part of the perineal nerve. The main trunk of the inferior cutaneous femoral nerve runs towards the digits in a sulcus contained between $m$. biceps femoris and $m$. semitendinosus. Its branches innervate the skin in the region of the muscles.

The nerve which in Carnivora innervates a similar region of the skin to that in the Primates behaves differently and has a different topography. While still within the pelvic cavity it is formed by two branches starting from the sciatic and pudendal plexuses (Fig. 1). Since the sacrosciatic ligament in the carnivores examined appears in the form of a narrow band stretching between the shaft of the sacrum and tuber ischii, the intrapelvic position of the initial part of this nerve is less clearly marked, like it is in Primates. The branch leaving the sciatic plexus is stronger than the next, which belongs to the pudendal plexus. The nerve trunk formed runs caudad in the direction of tuber ischii and is located pericentrally in relation to the ligament referred to. Near the posterior margin of this narrow ligamentous band the nerve under discussion may in Canidae run between its bundles and then enter the anosciatic pit. The terminal branchings of this nerve innervate the skin in the region of tuber ischii and the posterior-lateral side of the thigh.

The caudal cutaneous femoral nerve in the horse and tapir, as in the Primates, constitutes one of the nerves of the sacral plexus. It separates

1) Caudal cutaneous femoral nerve in other representatives of Mammalia. 
from the lateral surface of this plexus immediately behind the greater sciatic foramen (Fig. 2). Its initial part may be connected in a common trunk with the caudal gluteal nerve or run independently, in a course to the side of the initial part of the sciatic nerve. It then lies dorsad and parallel to the latter nerve and its proximal muscle branch. In the vicinity of this branch it proceeds in the direction of tuber ischii and vecupies its typical situation, that is, it passes ventrad from tuber ischii and dorsad from the greater femoral trochanter. On the exterior, subcutaneously, it emerges between the two parts of $m$. biceps femoris (tapir) or appears in a sulcus contained between the latter and m. semitendinosus (horse). At the level of the third trochanter this nerve divides into two branches. The upper-posterior branch is directed to the rear, and its branchings proceed in two directions. Some of them bend upwards in an arch and innervate the skin in the region of tuber ischii, others

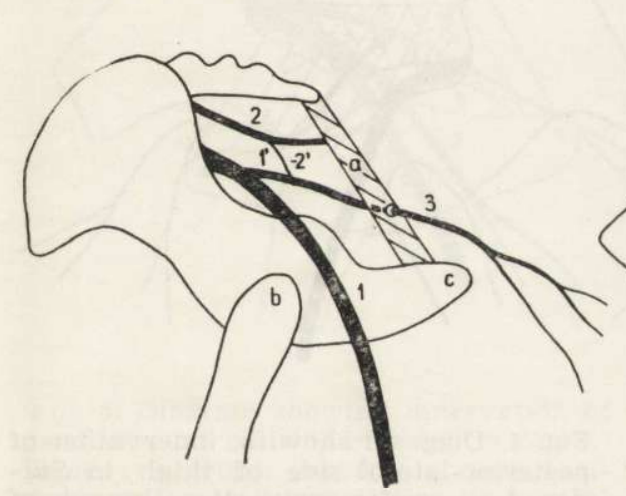

Fig. 1. Diagram showing innervation of posterior-lateral side of thigh in Carnivora. 1 - sciatic nerve, $1^{\prime}-$ branch of sciatic nerve, 2 - pudendal nerve, $2^{\prime}-$ branch of pudendal nerve, 3 - cutaneous branch, a - sacrosciatic ligament, b - greater femoral trochanter, c tuber ischii.

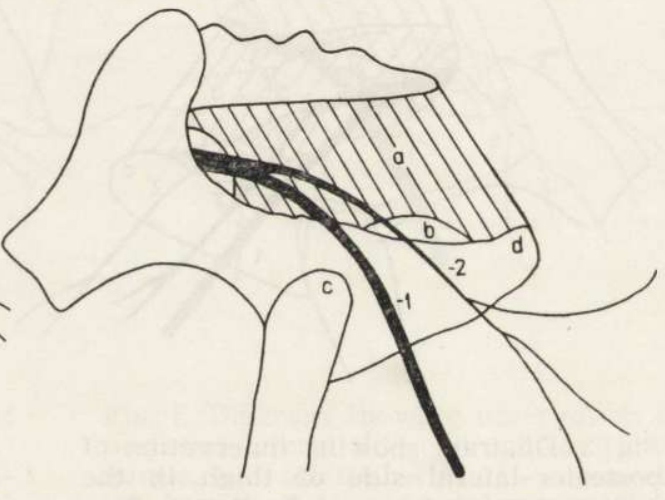

Fig. 2. Diagram showing innervation of posterior-lateral side of thigh in Perissodactyla. 1 - sciatic nerve, 2 - caudal cutaneous femoral nerve, a-sacrosciatic ligament, b - lesser sciatic foramen, c - greater femoral trochanter, $\mathrm{d}-t u$ ber ischii.

proceed towards the plantar side of the thigh and innervate the skin in the region of $\mathrm{mm}$. semimembranosus and semitendinosus. The second part of this nerve, that is, the lower branch, runs almost parallel to the bundles of $m$. biceps femoris, and innervates the skin of this region. In addition to fibres innervating the skin, the caudal cutaneous femoral nerve in the animals referred to has motor fibres extending to $\mathrm{m}$. semitendinosus.

In the Artiodactyla examined the question of the caudal cutaneous femoral nerve is somewhat varied. 
In representatives of three sub-orders: Suiformes, Tylopoda and Ruminantia, the region of the skin on the posterior-lateral side of the thigh is variously innervated. There are significant differences even within the same sub-order. This applies primarily to representatives of Suidae and to hippotamuses. In the latter there is some similarity to this nerve in Perissodactyla, namely the caudal cutanous femoral nerve, the behaviour of which is typical, begins from the lateral surface of the sacral plexus (Fig. 3). The difference observed in the behaviour of this nerve and the analogical nerve in Perissodactyla consists in the fact that at a relatively small distance from the place at which it leaves the plexus it divides into two separate branches, which run parallel to each other and to the sciatic nerve. The branch located more dorsad receives a weak

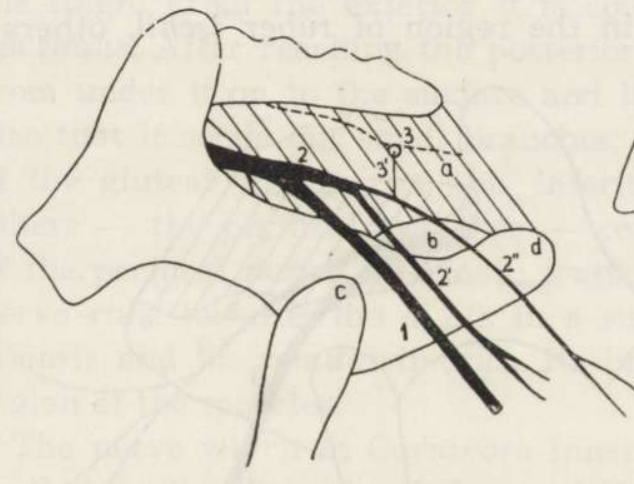

Fig. 3. Diagram showing innervation of posterior-lateral side of thigh in the hippopotamus. 1 - sciatic nerve, 2 caudal cutaneous femoral nerve, 3 pudendal nerve, $3^{\prime}$ - branch of pudendal nerve, a - sacrosciatic ligament, b - lesser sciatic foramen, cgreater femoral trochanter, $\mathrm{d}-$ tuber ischii.

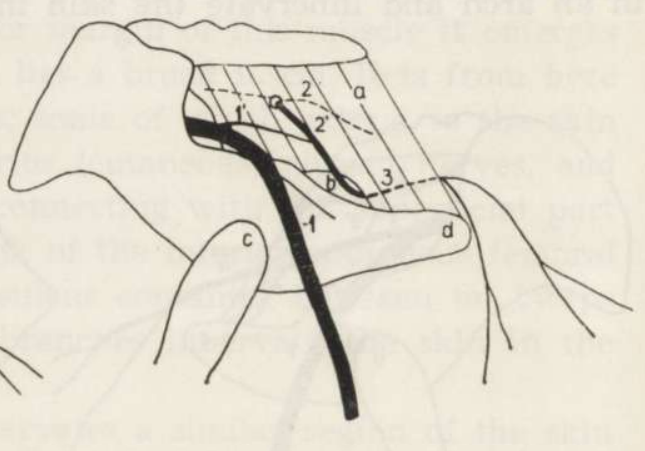

Fig. 4. Diagram showing innervation of posterior-lateral side of thigh in Suidae. 1 - sciatic nerve, $1^{\prime}-$ branch of sciatic nerve, 2 - pudendal nerve, $2^{\prime}$ branch of pudendal nerve, 3 - cutaneous branch, a - sacrosciatic ligament, b - lesser sciatic foramen, c - greater femoral trochanter, $\mathrm{d}-$ tuber ischii.

bundle of nerve fibres from the pudendal nerve. It pierces the sacrosciatic ligament and joins the branch referred to in its initial part. Both. branches proceed in the direction of tuber ischii, passing ventrad from it and after emerging from under the muscles covering them divide into a large number of branchings. Some of them, belonging to the dorsal branch, bending slightly upwards, innervate the skin of the region round tuber ischii and, passing from the lateral side in the Ferineal region, innervate the skin of this region. The branchings of the ventral branch proceed in the direction of the digits and innervate the skin of the lateral-posterior side of the thigh. 
The sensory innervation of the above regions differs in representatives of Suidae (Fig. 4), the relations observed being similar to those in Carnivora. As in the case of the latter, the participation of the pudendal nerve in the formation of the nerve under discussion can be observed. There is, however, a certain difference, consisting in the fact that this nerve does not actually form inside the pelvic cavity, since the branch of the pudendal plexus pierces the sacrosciatic ligament and runs for a certain distance on its lateral side and not far from the lesser sciatic foramen joins the branch of the sciatic plexus, which is far weaker than it. The nerve trunk formed in this way enters the pelvic cavity through the

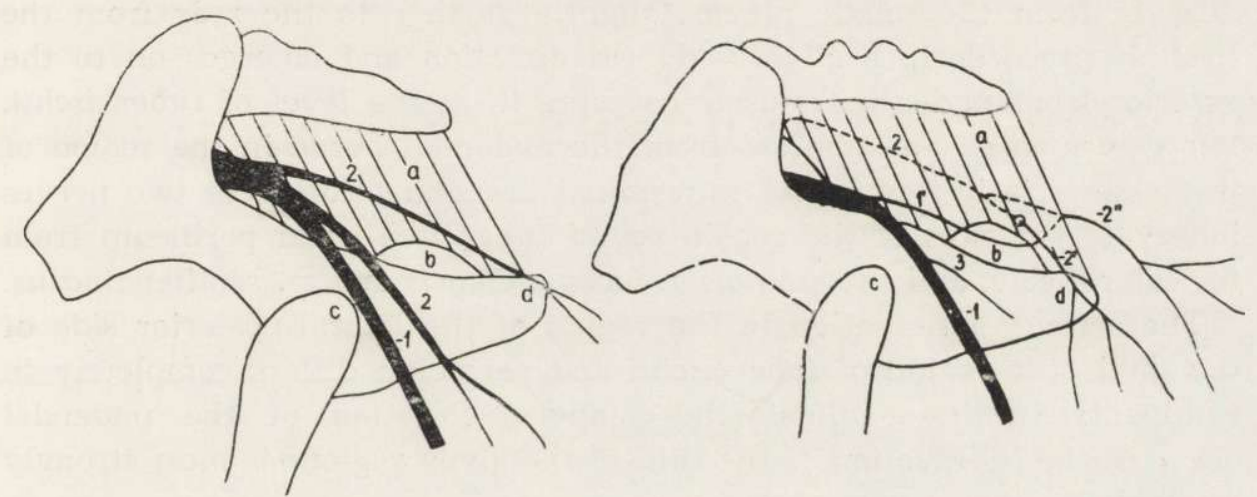

Fıs. 5. Diagram showing innervation of posterior-lateral side of thigh in Camelidae. 1 - sciatic nerve, 2 - caudal cutaneous femoral nerve, $2^{\prime}-$ its ventral branch, 2" - its dorsal branch, a sacrosciatic ligament, b - lesser sciatic foramen, c - greater femoral trochanter, $\mathrm{d}-$ tuber ischii.
Fig. 6. Diagram showing innervation of posterior-lateral side of thigh in Ruminantia. 1 - sciatic nerve, $1^{\prime}$ - connecting branch, 2 - pudendal nerve, $2^{\prime}-$ proximal cutaneous branch, $2^{\prime \prime}$ - distal cutaneous branch, 3 - muscular branch for $m$. biceps femoris, a - sacrosciatic ligament, b-lesser sciatic foramen, c - greater femoral trochanter, d tuber ischii.

above foramen. It is then directed slightly upwards and enters the anosciatic pit. This single nerve trunk often divides into two parts inside the pelvic cavity. In other cases this division does not take place until the anosciatic pit is reached. The region innervated by the two branches is the same as in the animals previously mentioned.

The question of the caudal cutaneous femoral nerve is different again in Camelidae. Although there is a typical caudal cutaneous femoral nerve in the llama and camel, which in a certain sense is similar to the relations found in Perissodactyla or hippopotamuses, certain differences occur here (Fig. 5). 
As distinct from Perissodactyla, the caudal cutaneous femoral nerve occurs in the form of two separate nerves, which is somewhat similar to the relations occurring in hippopotamuses. Unlike the latter, however, these are not two branches formed by division of the single initial part of the trunk of this nerve, but two separate nerves starting from the sciatic plexus. Certain differences are also observed in respect of the connection with the pudendal nerve.

One of these caudal cutaneous femoral nerves branches nearer the front forms the common gluteo-cutaneous trunk. It runs parallel to the sciatic nerve and, passing between tuber ischii and the greater femoral trochanter, extends subcutaneously to the thigh. The other branch leaves directly from the sciatic plexus, slightly further to the rear from the first. It proceeds in a slightly dorsad direction and emerges on to the exterior from under the muscle covering it, at the level of tuber ischii. It receives small anastomoses from the pudendal nerve in the region of the lesser sciatic foramen. The terminal branchings of these two nerves innervate the skin of the region round tuber ischii and perineum from the lateral side, and the skin of $m$. biceps femoris and $m$. semitendinosus.

The sensory innervation in the region of the lateral-posterior side of the thigh, the region of tuber ischii and perineum differs completely in ruminants. In these animals the competitive action of the pudendal nerve in the innervation of the skin in the given regions is most strongly marked (Fig. 6).

Although a branch leaves the sciatic plexus or nerve in a backwards direction and passes in a typical way between tuber ischii and the greater femoral trochanter, its purpose is not to innervate the skin, since it contains the motor fibres supplying $m$. biceps femoris. Therefore the region of skin innervated by the caudal cutaneous femoral nerve in the horse, camel or Primates, is innervated in ruminants by branches starting from the pudendal plexus or nerve. In the ruminants examined it proved possible to observe one (eland, nilgau, majority of sheep), two or even three (garna, musk-deer) branches which can be termed the proximal, middle and distal cutaneous branches. These branches are fairly distinctly distinguishable as early as the initial part of the pudendal plexus and nerve, as the position and course taken by bundles of nerve fibres are very characteristic in this part. Two layer-like forms - the profound and the superficial - are clearly visible. In its continuation the latter clearly separates from the trunk of the pudendal nerve and passes into a cutaneous branch or branches.

In those animals which possess only one cutaneous branch, this is strongly formed and widely branched. After separating from the trunk of the pudendal nerve it runs diagonally dorsad, extending to the po- 
sterior margin of the sacrosciatic ligament connested with the strong tendon of $m$. biceps femoris. This branch next enters the anosciatic pit, leaving the pelvic cavity dorsad from tuber ischii. Inside the pelvi: cavity it receives, in the majority of the individuals examined, a small bundle of nerve fibres belonging to the branch connecting the sciatic nerve. In the anosciatic pit, or slightly further on, a single cutaneous branch divides into two parts: inferior-lateral and superior-medial. The first of them proceeds on to the thigh, runs along its lateral side and innervates the skin in the area of $m$. biceps femoris. The second, the stronger of the two, greatly branching or even once again dividing into two parts, extends over the plantar side of the thigh and in the perineal region, innervating the skin in the region of $\mathrm{mm}$. semimembranosus and semitendinosus.

Two cutaneous branches occur in all the remaining ruminants examined (except the garna and musk-deer). The first of them, that is, the proximal cutaneous branch, could be treated as the counterpart of the inferior-lateral segment of the single branch in the previously-mentioned animals. This branch may leave from the initial part of the pudendal nerve or directly from the ventral branch $\mathrm{S}_{3}$ (muntiak, some of the sheep). Its initial part lies on the pericentral side of the sacrosciatic ligament, directed downwards and slightly dorsad. In the majority of the animals examined it leaves the pelvic cavity by piercing the above ligament not far from tuber ischii. Next, passing between the bundles of $m$. gluteo-biceps, it appears superficially in the fascia covering the thigh from the lateral side. In the reindeer, roe-deer and sometimes in the cow, this branch leaves the pelvic cavity in a slightly different way. In the first of these animals it leaves through the lesser sciatic foramen and joins the branch connecting the sciatic nerve. In the cow and roe-deer it behaves differently. After leaving the pudendal nerve it runs between the bundles of fibres of the sacrosciatic ligament, after piercing which it passes out from the pelvic cavity.

The second cutaneous branch, the distal branch, is usually more strongly formed than the preceding one and could be considered as the counterpart of the superior-medial part in those animals which possess a single cutaneous branch. In its course within the pelvic cavity this branch may receive weaker or stronger bundles of nerve fibres from the branch connecting the sciatic nerve. From the place at which it leaves the pudendal nerve the distal cutaneous branch passes in a dorsad-caudad direction to the anosciatic pit. It is in this place also that it may receive (in the majority of the cows examined, and also in the oryx, reindeer, roe-deer and some goats) a bundle or bundles of nerve fibres originating from the muscle branches of the pudendal plexus. 
After emerging from the anosciatic pit, or in sporadic cases whilst still in it, the distal cutaneous branch divides into two or three small branches. Their terminal parts innervate the skin in the region of $\mathrm{mm}$. semimembranosus and semitendinosus, the perineal region and in females the vulva also.

Yet another middle cutaneous branch occurs in the garna and musk-deer, in addition to the two cutaneous branches described. In the latter animal it begins, like the proximal cutaneous branch, directly from the ventral branch $\mathrm{S}_{3}$. The course and behaviour of this branch, and also that of the successive branch, the distal branch, is similar to the behaviour of the latter in the previously-mentioned animals, the only difference being that it does not receive anastomoses from the muscle branches of the pudendal plexus.

\section{DISCUSSION}

On the basis of the comparative anatomical studies made it can be said that the typical homological caudal cutaneous femoral nerve in man and the Primates occurs in Perissodactyla and some representatives of Artiodactyla (hippopotamus, llama, camel). In these animals it is one of the independent nerves of the sacral plexus. It leaves the pelvic cavity through the greater sciatic foramen and runs along the lateral side of the sacrosciatic ligament. It next passes between tuber ischii and the greater femoral trochanter. Unlike the relations found in man and the Primates, this nerve in the horse, tapir and llama, in addition to sensory fibres innervating the skin of the lateral-posterior side of the thigh, also contains motor fibres innervating muscles. A different type of innervation of the skin in this region occurs in all the other animals examined. In pigs this nerve, generally termed the caudal cutaneous femoral nerve, exhibits completely different topography and way of formation than the typical nerve bearing the same name. It is formed by two branches - a weaker one constituting part of the sciatic plexus and a second, stronger branch from the pudendal plexus. The latter, after piercing the sacrosciatic ligament, runs along its lateral side and then joins the previous branch. The nerve trunk formed in this way enters the pelvic cavity, which it next leaves dorsad from tuber ischii through the anosciatic pit.

A similar type of innervation to that in pigs can be observed in Carnivora, except that the branch from the sciatic plexus is stronger in comparison with the branch from the pudendal plexus. The place in which the nerve trunk is formed also differs, since it is formed inside the pelvic 
cavity and runs pericentrally from the narrow band of the sacrosciatic ligament.

It would appear that this nerve cannot be considered identical with the inferior cutaneous femoral nerve in man and the Primates. Its topography and way in which it is formed indicate that it is more homological with the nerve described in pigs. The conclusion may also be reached that the nerve fibres of the sciatic plexus, which in Primates, Perissodactyla and some representatives of Artiodactyla form the caudal cutaneous femoral nerve, are joined in a different nerve trunk in Carnivora and pigs. This is even clearer in the next type of innervation of this region in ruminants. In these animals the participation of nerve fibres from the sciatic plexus which form the nerve innervating the skin of the posterior-lateral surface of the thigh and the perineum is only very slight. The skin of this region is innervated by one, two or even three branches of the pudendal plexus. Located on the pericentral side of the sacrosciatic ligament, they leave the pelvic cavity either by piercing this ligament or by entering the anosciatic pit. None of these branches, however, can be considered as homological with the typical caudal cutaneous femoral nerve in the previously-mentioned animals. It would be possible to consider the muscle branch existing in ruminants, possessing similar topography to that of the typical caudal cutaneus femoral nerve, as homological with this nerve, except that it has lost the sensory fibres for the skin. During the course of phylogenesis these fibres shift$€ d$ to the region of the pudendal nerve. The fact that a large number of authors term this particular branch the caudal cutaneous femoral nerve probably accounts for so much erroneous and contradictory information being given on the subject of this nerve.

The behaviour of the caudal cutaneous femoral nerve can be taken as an example, accentuating the interesting problem of the competition between two nerves (sciatic and pudendal) in the innervation of the same region. The nerves reaching this region of the skin are most certainly not nerves homological in different species. Consequently the next problem arises of establishing a criterion for comparison of certain nerves in different species, and determining their identity. It is a question which of the following three: origin from the same segments, area of innervation and topography, is to be considered as most important. In my opinion when a different number of lumbar and sacral nerves occur in different species of animals the criterion of origin from the same segments plays no important role. There remains therefore either the area of innervation or topography. In my own studies I held the criterson of topography to be the most important, and this is also confirmed in practical work, e.g. when experimental studies are carried out by 
doctors of medicine on laboratory animals (monkey, dog, cat, sheep). If the criterion of region of innervation were recognized and applied it would be necessary to consider the nerves innervating the skin of the lateral-posterior side of the thigh in Carnivora and ruminants as exactly corresponding to such nerves in Primates, which would produce highly undesirable results. Although the area innervated is the same, the topography is completely different and it is this last consideration which plays a decisive role when carrying out surgical operations or anaesthesia.

The studies made permitted of distinguishing three main types of innervation of the posterior-lateral side of the thigh.

The first type is characterized by the presence of the typical caudal cutaneous femoral nerve (Primates, Perissodactyla, Hippopotamidae, Tylopoda);

The second type is characterized by occurrence of cutaneous branches originating from the branchings of both the sciatic and the pudendal plexus (Carnivora, Suidae);

In the third type there are cutaneous branches starting from the pudendal plexus (Ruminantia).

In view of the fact that the typical caudal cutaneous femoral nerve also occurs in Marsupials, Insectivora and the lower Lemuroidea, that is, in primitive mammals, it can be assumed that its presence constitutes a primitive character. On the other hand its replacement by other cutaneous branches is a phylogenetically later phenomenon. The fact merits emphasis that the presence of any one of these types of innervation constitutes a feature characterizing the smaller systematic units, e.g. Suidae and Hippopotamidae. The presence of the typical caudal cutaneous femoral nerve in the latter animal leads to the assumption that the replacement of this particular nerve by other cutaneous branches in pigs and ruminants is of a convergent character. This observation may also apply to other mammals characterized by absence of the typical caudal cutaneous femoral nerve (e.g. Carnivora).

\section{REFERENCES}

1. Ar łamowska-Palider A., 1969: Morphology of the sacral plexus of the tapir. Acta theriol., 14, 12: 313-320.

2. Arlamowska-Palider A., 1969: Badania morfologiczne splotu krzyżowego owcy. Zesz. Nauk. WSR Wet. 25: 161-175, Wrocław.

3. Franzke H. \& Heinze W., 1961: Zur Blutgefäss und Nervenversorgung der Schulter und Beckengliedmasse beim Reh. Anat. Anz. 110: 375-393, Jena.

4. G olle r H., 1963: Kerngebiete des Rinderrückenmarkes. Zbl. Vet. med. R. A. 10: 51-66, Berlin. 
5. Habel R., 1966: The topographic anatomy of the muscles, nerves and arteries of the bovine female perineum. Amer. J. Anat. 119: 79-95, Philadelphia.

6. He inze W., 1964: Die Muskulatur der Hintergliedmasse vom Giraffa camelopardalis angoliensis mit einigen Hinweisen zur Blutgefäss- und Nervenversorgung. Anat. Anz. 115: 476-484, Jena.

7. Heinze W. \& Franzke H., 1962: Zur Nervenversorgung der Beckengliedmasse der Rothirsche. Anat. Anz. 111: 365-379, Jena.

8. Henning P., 1965: Der $M$. piriformis und die Nn. clunium medii des Hundes. Zbl. Vet. med. R. A. 12: 263-275, Berlin.

9. Humel P., 1965: Die Muskel und Hautnerven des Plexus sacralis des Hundes. Anat. Anz. 117: 385-399, Jena.

10. K a la šnik I. A., 1952: Anatomo-topografičeskie dannye o krestcovom i tazovom spletenijah u svinej. Sbor. Trud. Hark. Vet. Inst. 21: 432-444, Harkov.

11. K o c h T., 1965: Lehrbuch der Veterinär-Anatomie. G. Fischer, 3: 307-346, Jena.

12. M a r ciniak T., 1965: Anatomia prawidłowa człowieka. Państw. Zakł. Wyd. Lek. 3: 276-308, Warszawa.

13. Martin P., 1938: Lehrbuch der Anatomie der Haustiere. Schickhardt-Ebner 3: $1-560$, Stuttgart.

14. May N. D. S., 1964: The anatomy of the sheep. Univ. of Queensland Press: $1-35$, St. Lucia.

15. Miller M. E., 1964: Anatomy of the dog. W. B. Saunders Co: 533-625, Philadelphia.

16. Popesko P., 1969: Atlas anatomii topograficznej zwierząt gospodarskich. Państw. Wyd. Rol. Leśn. 3: 1-207, Warszawa.

17. Preusch oft H., 1961: Die Nerven der Hinterextremität des Gorilla (Gorilla gorilla). Anat. Anz. 110: 353-374, Jena.

18. Reimers H., 1913: Der Plexus lumbalis und sacralis des Rindes und Schweines. Inaug.-Diss. Leipzig.

19. Ryžih A. F., 1962a: Pojasnično-krestcovoe spletenie lošadi i vzaimosvazi ego S simpatičeskim stvolom. Uč. Zapis. Kaz. Vet. Inst. 85: 43-51, Kazan.

20. R y ̌̌ih A. F., 1962: Morfologija pojasničnogo i krestcovogo spletenija krupnogo rogatogo skota. Ib. $52-\varepsilon 0$.

21. Ryžih A. F., 1964: Pojasnično-krestcovoe spletenie i nervy tazovyh konečnostej domašnej svini. Ib. 93: 22-28.

22. Schreiber J., 1956: Die anatomischen Grundlagen der Leitungsanästhesie beim Rind. IV Teil. Wien. Tierärztl. Mschr. 43: 273-287, Wien.

23. Serwatka S., 1966: Nerwy rdzeniowe żubra (Bison bonasus L.). Maszynopis pracy doktorskiej. Warszawa.

24. Sisson S. \& Grossman J., 1960: The anatomy of the domestic animals. W. B. Saunders: $1-972$, Philadelphia.

25. Z i e g le r H., 1931: Die Innervationsverhältnisse der Beckenmuskeln bei Haustiere in Vergleich mit den jenigen beim Menschen. Morph. Jb. 68: 1-45.

26. Z obundžija M., 1967: Prilog poznavanju odnosa izmedu n. cutaneus femoris caudalis i n. gluteus caudalis u konja. Veter. Archiv 37: 299-306, Zagreb.

Accepted, March 2, 1971.

Department of Animal Anatomy,

College of Agriculture,

Wrocław 12, Kożuchowska 1.

Acta theriol. 26 


\section{Anna AREAMOWSKA-PALIDER}

MORFOLOGIA I TOPOGRAFIA NERWU SKORNEGO DOOGONOWEGO UDA

\section{Streszczenie}

Przeprowadzone badania miały na celu szczegółowe opracowanie zagadnienia nerwu skórnego doogonowego uda u przedstawicieli następujących rzędów: naczelnych, mięsożernych, nieparzystokopytnych oraz trzech podrzędów: świniokształtnych, wielbłądokształtnych i przeżuwaczy. Badania te wykazały, że typowy nerw skórny doogonowy uda, homologiczny nerwowi skórnemu dolnemu człowieka występuje tylko u naczelnych, nieparzystokopytnych, wielbłądoksztaltnych i hipopotamów. U pozostałych badanych zwierząt nerw ten został zastąpiony innym nerwem na co wskazuje jego odmienna topografia i sposób powstawania. Bowiem w przeciwieństwie do typowego nerwu skórnego doogonowego uda jest on nie jednym z nerwów splotu kulszowego, lecz stanowi twór złożony z odgałęzień nerwu kulszowego i sromowego lub tylko splotu sromowego. Odmienny jest również sposób opuszczania jamy miednicowej; nie otworem kulszowym większym lecz przez wejście do dołu kulszowo-odbytnicowego lub przez przebicie więzadła krzyżowo-kulszowego. Zasadniczo można by wyróżnić trzy główne typy unerwienia tylnobocznej strony uda. W typie pierwszym obecny jest typowy nerw skórny doogonowy uda. Typ drugi (obserwowany u mięsożernych i świniowatych) cechuje występowanie nerwu skórnego biorącego początek z odgałęzień nerwu kulszowego i sromowego. W typie trzecim charakterystycznym dla przeżuwaczy pojawiają się gałęzie skórne pochodzące ze splotu sromowego. 